\title{
Integrating Dimensions of Sustainable Development Goals (SDGs) Within Umranic Framework
}

\author{
Atih R. Dariah ${ }^{1}$, Muhammad S. Salleh ${ }^{2}$, Mahyudin bin Yahaia ${ }^{3} \&$ Ade Y. Mafruhat ${ }^{1}$ \\ ${ }^{1}$ Faculty of Economics and Business, Universitas Islam Bandung, Indonesia \\ ${ }^{2}$ Centre for Islamic Development Management Studies (ISDEV), Universiti Sains Malaysia, Pulau Pinang, \\ Malaysia \\ ${ }^{3}$ Faculty of Islamic Development Management, Universiti Islam Sultan Sharif Ali (UNISSA), Negara Brunei \\ Darussalam
}

Correspondence: Atih R. Dariah, Faculty of Economics and Business, Universitas Islam Bandung, Indonesia. E-mail: ardariah.68@gmail.com

Received: October 12, 2019

Accepted: November 1, 2019 Online Published: November 28, 2019

doi:10.5539/jsd.v12n6p82

URL: https://doi.org/10.5539/jsd.v12n6p82

\begin{abstract}
This paper aims to suggest an integration of dimensions, especially economic, social, environmental, and politics that are embedded in Sustainable Development Goals (SDGs) within a framework called Umran. This Umranic framework hails from the idea of distinguished Muslim philosopher, historian and sociologist Ibn Khaldun, that is based on Islamic doctrines. As the present integration of the dimensions seems to be problematic, an exploration into the integration within Umranic framework is believed to be potentially a contributive endeavor. Based on an overview of literatures and a content analysis, this paper found that integrating dimensions of SDGs within the Umranic framework appears in the triangle of relationship between God, humans, and environment. This triangle exists in the form of an Islamic economic system. In this system, economic activities of natural resource utilization in various types of ownership undertake the sustainability dimension, that is the environmental protection and the promotion of equitable distribution, followed by the implementation of management of ownership and distribution rights according to Islamic rules. The pre-requisite on the part of the players is the high levels of spirituality. The application of this Islamic economic system followed by its political dimension will guarantee the achievement of SDGs even though it needs adjustment to a number of SDGs' indicators that are not in accordance to Islamic teachings.
\end{abstract}

Keywords: SDGs, sustainable development, Umranic theory

\section{Introduction}

In its third year, the presence of Sustainable Development Goals (SDGs) as a new agenda for the direction of global development has been increasingly accepted by the stakeholders of development in the world. SDGs was formally launched in January 2016 with 17 goals and 169 targets. Three years into the implementation of the Agenda, countries are translating this shared vision into national development plans and strategies.

Our previous study, the 'Comparative Study of Sustainable Development Planning in Indonesia, Malaysia and Negara Brunei Darussalam showed that three countries have their own specific institutional agencies dealing with the implementation of SDGs. They undertake similar steps, i.e. performing alignment between the existing plan documents with SDGs, examining the indicator and data availability for monitoring and evaluation, establishing communication, and building capacity with all stakeholders.

Each target and indicator represents each goal without viewing SDGs as a network. Thus, there is no focus on the 17 goals or which goals should be prioritized that have the biggest multiplier effect (snowball effect) towards achieving other goals. Nevertheless, the 17 goals actually have a connection and dependence on each other; influence and determine each other either positively, negatively, or neutrally.

The Sustainable Development Goals Report (United Nation, 2018) revealed that transitioning towards more sustainable and resilient societies requires an integrated approach which recognizes that challenges of sustainable development - and their solutions - are interrelate. The challenge of integrating the three dimensions has long been the subject of discussion for many parties. Weitz et al.(2015) proved SDGs in an analysis of the relationship 
of water, energy and food target. Achieving one target is dependent on another. For example, water access is dependent on energy availability, and vice versa. One target imposes conditions on another. For instance, sustainable management of water resources conditions how access to water is provided. Progress on one target reinforces progress on another, that is, improving water use efficiency facilitates providing access to water. Blanc (2015) showed that two of the proposed goals, SDG 12 on sustainable consumption and production (SCP) and SDG 10 on inequality, provide critical connections among other goals and make the SDGs more tightly linked as a network. Blanc analized the integration of between goals using network analysis techniques which solely based on the target slice between goals that strongly related. This method, while seemingly straightforward, is of course subject to different interpretations of the wording of the targets. Due to different interpretations, other view emerged stating that eradicating hunger and ensuring food security is a bottom-line requirement for achieving sustainable development and wellbeing. Different results indicate the absence of foundation of thinking that can be used as a reference in conducting integration analysis. In same opinion, Nilsson et al (2017) state that interactions between SDGs currently have a weak conceptual and scientific underpinning.

Finding the integration of the three dimensions should be traced from its philosophical foundation. Philosophically scholars such as Hajer's in Roberts and Chan (1997), Redclift in Briassoulis (2001), Counsell (1999), Holden (2008), Hafsa and Aström (2011), proposed that sustainability need fundamental changes in the ideology, transformation of cultural attitudes and behavior, paradigm shift, institutional reform supported by appropriate political and institutional structures. Explicitly, the United Nations (2015) has stated that the integration of economic, social and environmental dimensions requires shifts in attitudes, behaviors, and knowledge competencies. Shifts in attitudes take place at two levels, i.e. the cognitive and affective levels. When the emphasis on these two is explained in systems thinking as the core of many problems, the researchers believe that the two levels can be built from the religious side. For this, we offer the Umranic framework that has been put forward by Ibn Khaldun, a well-known Muslim sociologist.

\section{Methods}

This research is basic/pure research, elaborating the normative framework related to sustainable development contained in Al-Qur'an and Hadith. The data obtained from the primary sources of Al-Quran and Hadith are concerned such as environment, earth, nature, man, Allah as creator, justice, property rights. To analyze the meanings of certain words from Al- Qur'an, the technique used was content analysis, conducted qualitatively (Chalil, 2009). Content analysis is an effort of examining the meanings of the content of a form of information in the forms of document, poetry, painting, written speech, normative text or law (Babbie, 1980). It attempts to research ideas, concepts, and values of various thoughts that will be made into inference through efforts of finding the characteristics of messages, and it is done objectively and systematically. Other equally important sources of data or information were the various research results on sustainable development in Islamic perspective.

The pattern of thinking used in the study is called "induction", a method of logical reasoning that obtains or discovers general laws from particular facts. To justify the method of induction is more effective we use semantic analytical and comparative method based on the teaching of Islam and historical facts as its tool to reach a scientific result. The method of induction used in the science of physics is different from the method of deduction used in the logic. This difference is significant because the induction method is through reasoning and sensory processes that generate the outcome of the observations or premise based in the results of research and experiments. Induction methods used in science have to be done in such a way as laws and regulations, even if true and came from Allah, but it not clearly stated and in detailed either in the Al-Qur'an or Hadith. Legal and regulatory science in the Qur'an may be characterized as "raw material" that requires extensive processing and are still open to be discussed and researched.

\section{Finding on Umranic Theory for SDGs Dimensions}

From the aspect of language, 'umran originated from the root word amara which gives the meaning of "affluence" and "prosperity" due to dense population and abundance in business, industry, and agriculture (Babbie, 1980 \& Mustafa, 1972). From the same root word arise the terms 'amir and ma 'mur which refers to the region in which umran possesses a large population, successful development, knowledgeable, highly cultured due to the existence of cooperation and consensus among society as well as a just ruler. Generally speaking, from the context of language it refers to a situation and atmosphere which possess peace, success, expertise, luxury, and affluence, large population and available job opportunities in which unemployment does not exist (Babbie, 1980).

The Science of 'Umran is divided into three areas, which is 'ulum naqliyyah (religious knowledge), 'ulum 
'aqliyyah and 'ulum lughawiyyah. Each of these areas of knowledge contain numerous types of sources and functions. 'Ulum naqliyyah is the religious knowledge sourced by the revelation that is contained in ayat muhkamat (clear defined and have section, methods and functions). 'Ulum 'aqliyyah is the academic knowledge sourced by understanding that is contained in ayat mutashabihat which have unclear definitions and meanings and also has its divisions, methods and functions.

Tools ('ulum lughawiyyah) is knowledge of languages or knowledge of equipment relating to communication and connections between the fields of knowledge that have been studied, whether it is religious knowledge or academic knowledge. For example, the function of Arabic language is to read and understand the Holy Quran, the Prophet' hadiths and religious books. The function of English language is to understand the knowledge of science and technology. Malay language is to understand the Malay's customs and traditions. Aside from that, the function of languages are to communicate between individuals and to form an understanding and cooperation among society to build a community and nation.

The theory of 'Umran is created specifically to manage mankind and natural resources for the purpose of development based on the philosophy of Islamic management and development which is characterized as holistic, amalgamated, hands-on, and in line whether in theory or practice.

The concept Uluhiyyah, Allah the One the Almighty, the All-Wise, and no partner to Him, and He creates all creatures, whether in the heavens or on the earth, the tangible and the intangible. God has sent Prophets and the apostles and the Holy al-Qur'an al-Karim as a guide for life in this world and the hereafter. Man cannot invent a lie against Allah Subhanahu wa Ta ala because He was the One who made man, and man cannot live without God. Man as a servant of God was commanded to follow and abide by the laws and regulations that God created. At the same time, humans are made of earth (clay) commanded and tasked to develop and prosper on the earth, and after that Allah ordered man to ask for forgiveness and repent to Him (al-Qur'an, Surah Hud: 61).

Allah created the universe for human life and to worship Allah, for society and the environment. Man's relationship with Allah, human relations among people, and between people and nature has always been perfect. Thus, Allah, man, and nature are in the chain and "Triangle" as illustrated in Figure 1, and the three are inseparable from one another. This does not mean the union between Allah and man and nature, as alleged by the adherents of the doctrine followers Wahdah al-Wujūd (Consolidation exist) by Ibn al-'Arabi and also transmitted by Hamzah Fansuri in the Malay world, but it means man and nature is a testimony to the existence and greatness of Allah the Creator. This doctrine is known as Wahdah al-Syuhud (attestation of the existence of Allah) made popular by Nur al-Din al-Raniri a Sunni in Aceh.

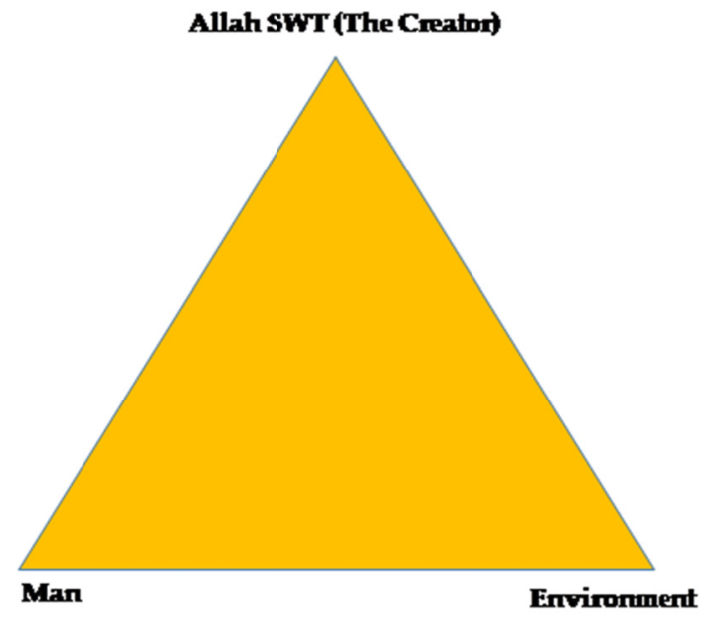

Figure 1. Triangle of Allah, man, and nature

There are three main things mentioned in above paragraph, namely Allah, man and earth (the environment) as a development that must be maintained and managed in accordance with the laws and regulations that Allah created. Islam is the religion of Allah SWT and how to live a full and a complete way of life that involves two aspects of life, internal and external. The internal aspect is to believe in Allah SWT, the angels, the scriptures and the messengers. The external aspect is the relationship between a human with Allah SWT (hablum min Allah) 
and the relationship between a human with other humans (hablum min nas) and the human relationship with the environment as a source of life. Allah has made the earth for humans to live together with other beings on the earth, whether animate or inanimate.

Humans have three elements: body, mind and spirit and each one has its own function and should be used properly and thoroughly. Humans have an advantage compared with other beings, because it is Allah Subhanahu wa Ta ala who has made man as the Caliph on earth. Humans are liable to inhabit the earth so that humans can live in peace and prosperity and they worship the one God who has made all the creatures on the earth, in the sky and the space in between them.

The surrounding environment, the components that make up the environment excluding humans are inanimate matter such as the sea, rivers, hills, mountains, etc. Its functionality and usefulness in life. Wild plants, fruit trees, vegetables, wildlife, animals, etc Its also functionality and usefulness in life.

\section{Discussion on Integrating SDGs Dimensions in Umranic Framework}

When the Umran Theory is used as a basis of thinking to place all four dimensions, it can be simply illustrated by Figure 2.

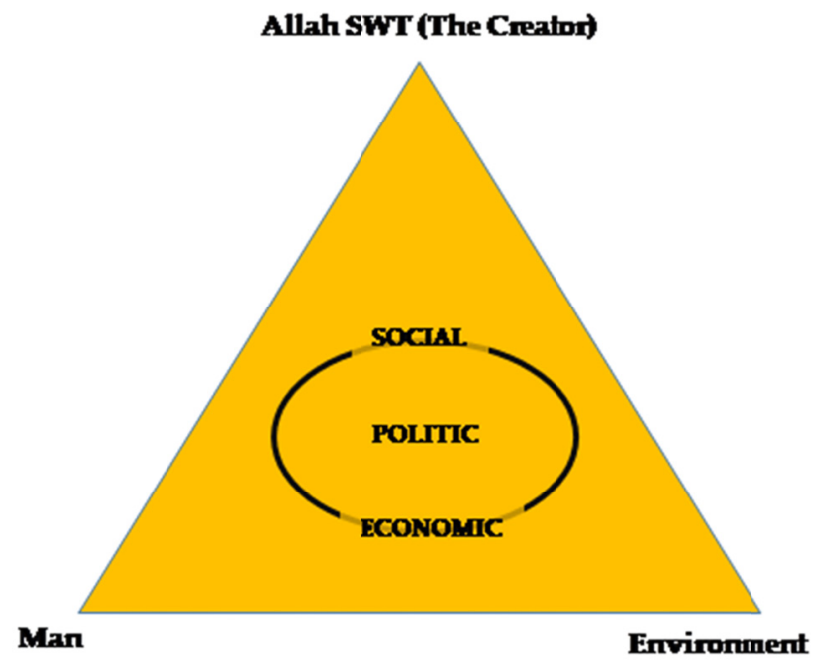

Figure 2. Sustainable development in Umranic framework

The science of 'Umrān is implemented in the form of a "triangle", starting with faith in Allah angels, Holy Books (Torah, Bible, Psalm and al-Qur'an al-Karim), the Apostles, and the Day of Judgment. Humans have an advantage compared with other beings, because it is Allah Subhānahu wa Ta'ālā who has made man as the vicegerent of God on earth.

The existence of human beings as the vicegerent of God on earth is identical to the effort of prospering the earth through the utilization and distribution of all resources in compliance with Allah's will. The utilization and distribution of all resources is the core of economic activity, and when it must be in line with Allah's will the approaches and patterns of utilization and distribution will certainly be based on Islamic teachings. Therefore, there will be a specific rule of conduct related to that matter and adjustment to the organization's needs in the implementation. This is where the importance of politics framing the rules of the game and human relations in prospering the earth. The following four sub-chapters are the explanation of how the Umranic Framework works.

\subsection{The Principal of Nature and Environment}

A Muslim believes in the existence of Allah SWT, the Creator of the earth, the sky, and everything in it. Natural resources and the environment are Allah's creations functioning to fulfill the life missions of a Muslim. Allah has created everything in balance. According to Nasr as quoted from (Mustafa, 1972), Islam, human beings, and the universe are in equilibrium, interrelated, and mutually completing. Allah is the Creator and Guardian of their sustainability. The universe was created with hikmah. The number, quantity, and quality have been determined perfectly, and each has been given its own roles. Every creation has its own goals. The number of resources 
created has been accounted for in order to cater to the needs of human beings.

Al-Qur'an depicts environmental equilibrium in several words, 'adl', 'qadar', and 'mouzoon'. The earth and ecosystem have functioned in their limitations and tolerance. There are several keywords in resource utilization, namely efficient and effective (Aziz \& Ulfah, 2010) and sustainably (Abdurrahman, 2012).

For sustainability, Abdurrahman proposes ethics which should be based on the conceptual framework constituting: tauhid (monotheism that Allah is the Only God), ibadah (devotion, having the value of charity), 'ilm (knowledge searched in an attempt of glorifying Allah), khilafah (exploiting and preserving the nature), amanah (being honest in treating the nature and just in empowering it), 'adalah (balance, where violators of amanah will be rebuked by the prevailing law), jamal (beauty, beuatiful phenomena should not be damaged), and halal-haram. As a consequence, the efforts of exploiting natural resources and the environment should be planned simultaneously in the context of its protection. The Qur'an equalizes protection of environments with the protection of religion (al-Nahl:90, al-Zumar:10, al-A'raf:56), and with the protection of life (al-Maidah:32, al-Nisa:29).

Allah SWT repeatedly describes and reminds humans about the existence of nature. The Holy Qur'an in Surah al-Nahl: 3 states that He created the heavens and the earth in truth. The Qur'anic Interpretation of Unisba Juz XIV explains that the truth is that Allah creates the heavens complete with all objects in it and creates the earth the same way under His wisdom and provision; both are arranged neatly, none at all misplaced (LSIPK, 2017). Then in Surah an Nahl: 48-49, it is said that to Allah SWT prostates whatever in the heavens and whatever is on the earth of creatures. Quranic verses in al-Hashir: 1, al-Taghabun: 1, al-Isra: 44 state that nature and humans exalt Allah SWT. Nature is a sign of the greatness of Allah (Ali Imran: 190, Yasin: 33-35). Nature is a medium of Iktibar (example/lesson), tasyakur (thankful), and dhikr (Al-A'raf: 185, Yunus: 101, an_Nahl: 5-8, 10-13, Yasin: 71-73), and nature as God's favor (Lukman: 20, Ibrahim: 32-34). Surah al-Ahzab: 72 states that this nature is part of the trust of Allah SWT. Surah Ahaad: 72, al-Isra: 70 say that nature is a medium for building civilization. Surah al-Baqarah: 33 emphasizes that nature provides inspiration in building knowledge and functions as a medium for economic development (al-Naml: 60). Nature is adornment and beauty (al-Shaffat: 6, al-Nahl: 88).

All the verses above are the guideline in building deep awareness of the environment so that the activities of utilizing natural resources become an integral part of the implementation of beliefs and worship to Allah SWT. A real practice on such matter has taken place in Malaysia . By taking the excerpts from the Qur'anic verses that forbid humans from vandalism as their foundation, members of the Agro Belantik Sik Bhd Cooperative have agreed not to run agricultural activities that bring harm to the surrounding environment. What is important for the cooperative is their responsibility as God's servants on this earth who understand the prohibited things and try to correct the damaged caused, especially after there are rules that allowed them to do so. The Agro Belantik Sik Bhd Cooperative Institute has carried out organic farming activities focusing on planting rice organically at SRI Lovely. The advantages of planting rice organically are free from the use of haphazard chemicals and aim to maintain the soil fertility and overcome the pests. This means that planting rice organically does not damage the soil nor pollute the surrounding environment (Yusnita, 2014). Environmental awareness formed by religious faith is expected to be the best initial solution to maintain and control environmental damage so that the SDGS goal number $6,7,13,14,15$ can be achieved.

\subsection{Islamic Economic System}

Distribution or allocation of resources and distribution of development outcomes, the target to be met should be done with justice. This has been the focus of SDGs 10. What is meant by being just, requires the power beyond human's mind, and the answer is given by the Islamic economic system (Triono, 2012). The Islamic economic system is a comprehensive system able to meet the basic needs of society, either clothing, food, shelter, health, education, and security. Thus, it discusses the way to meet everyone's basic needs instead of how to produce economic goods per se (Al-Nabhani, 2010).

The three principles that have to be considered to build Islamic economic system are ownership/property rights, ownership/property rights management, and wealth distribution (Al-Nabhani, 2010). Regarding ownership, Islam regulates its nature, cause, and type. Naturally, the property belongs to Allah SWT (Surah an-Nuur: 24) which is given to humans (Surah al-Hadid: 7) and will be held accountable for how it was earned and used for. According to al-hadith, human will be questioned about four things in the hereafter. Firstly, how his life is spent; secondly, how his body is used during his life; thirdly, how he acted upon his knowledge; and fourthly, how he earned and spent his wealth for. Comprehensive understanding of the meaning of this verse will lead to the wise conduct in managing ownership. 


\subsection{Islamic Political Economy}

The implementation of Islamic economic systems cannot be separated from Islamic political economy, namely the application of various policies ensuring the fulfilment of all basic needs of each individual in society as a whole, accompanied by guarantees that enable them to meet complementary needs in accordance with their abilities (Al-Maliki, 2009).

There are four principles of Islamic political economy (Nasim, 2012). Firstly, everyone is an individual who needs to fulfill their basic needs; secondly, fulfillment of basic need is carried out as a whole (complete); thirdly, it is Mubah (permissible) for individuals to earn money (work) with the aim of gaining wealth and increasing prosperity; and fourthly, noble values (Islamic Shari'a) must dominate (and become a prevailing rule for) all interactions involving individuals in society.

The first and second principles concern the fulfillment of basic needs that cover two categories: goods (food, clothing, and house) and services (security, education, and health). The implementation of Islamic political economy must suffice decent human living standards, meaning there is no poverty. Therefore, prioritizing the fulfillment of basic needs of goods (no poverty) as the first goal of SDGs is already appropriate, which then reinforced by the fulfillment of food needs (zero hunger) as the second goal. Hence, the second goal is actually a subset of the first one. Meanwhile, the 11th SDGs goal is related to efforts of fulfilling housing needs.

Next is the fulfillment of basic services in the form of health and education. The state directly guarantees the health of all citizens (Muslims \& non-Muslims) by providing free medical and health facilities. The state also provides decent yet affordable even free educational facilities. SDGs are very concerned about these two primary service needs as it is stated in their third goal of ensuring healthy lives and promoting well-being for all at all ages, and the fourth goal of ensuring inclusive and equitable quality education and promoting lifelong learning opportunities for all. Regarding security guarantees, according to Islam, the state directly guarantees the security of all citizens (Muslims \& non-Muslims) by applying strict rules to anyone who harm the soul, honor, blood, and property of others as it is stated in the goal of 16th SDGs. Thus, the 5 goals of SDGs aforementioned have answered the demands of fulfilling basic needs. The third principle is clearly stated in the 8th goal of SDGs, namely to promote sustained, inclusive, and sustainable economic growth, full and productive employment, and decent work for all.

Based on the three sub-chapters above, it appears that Islamic teachings encompass all aspects of life. When the Umranic framework is illustrated as a triangle of human-God-environment relations, there are crucial things in the context of achieving SDGs as follows.

Human relation with himself means how each individual manages himself to be an insan kamil (a perfect man, an exemplary of human being) and has the commitment to perform excellent activities as if Allah sees it (excellent 'Ihsan'), not as an economic tend-to-be greedy creature. 'Insan' is a becoming being, which means human beings move permanently in the direction of Allah towards the ideal perfection (Shari'ati, 2005).To achieve the embodiment of an insan kamil, there should be an integrating education between mind and heart, knowledge and deed, daruri (self-evident) knowledge and nazari (theoretical) knowledge, fard ayn knowledge and fard al-kifayah (comunal obligation) knowledge (Salleh, 2009). In this context, Islamic teachings provide mahdoh (all forms of) worship facilities as a manifestation of human relations with Allah. Therefore, it can be said that the concern for the environment is not merely awareness without a foothold, but it is a part of the appreciation of human existence as a servant of Allah who must prostrate and subservient Him, the Creator.

Interaction between human beings consists of the relationship between individuals or groups in various aspects that shape a society. The establishment of Muslim communities have the characteristics of ta'awun (mutual aid), takaful (mutual share of the burden), and tadhomun (having solidarity). Interestingly, these characteristics emerge like two sides of a coin where an individual figure is able to display behavior of insan kamil and at the same time managing assets both in terms of market mechanisms and non-market mechanisms. The mechanism in question is in the form of teachings and its implementation processes either mandatory or voluntary with the achievement of merit and heaven. Zakat, infaq and alms are instruments of social justice (non-market mechanisms). Meanwhile, market mechanism is related to asset development through various economic activities in a variety of ownership which includes salary or wages, land lease, and profit. The practice of Islamic business through a variety of Syirkah (partnership) principles promotes profit sharing which guarantees equitable distribution of income when business people have a high moral standing. The results of our previous research showed that income distribution becomes more equal when Islamic principles are internalized. From some of the propositions given, we conclude that wage level will be determined not only by perception or the mind set of capital owners and workers on the value of their assets, but also the standing moral of entrepreneurs and capital 
owners (Dariah, 2014). Thus, the realization of Muslim community as explained above cannot be separated because of the strength of the relationship with Allah SWT.

Human relationship with nature, where natural resources and environment are Allah's creations functioning to fulfill the life missions of a Muslim. Life goes and depends on the space, namely the Earth as one of the planets of the whole system in the universe. Al-Jayyousi (2012) describes the Earth as a huge circle, in which life is a small circle inside it. It means that human life is a part of the whole ecosystem. With such a position, the exploitation of natural resources and the environment should be accompanied by comprehensive understanding, belief, and responsibility.

\section{Conclusion}

Integrating the dimensions of SDGs within the "Umranic framework" must be built from fundamental things, namely beliefs, conviction, and faith in the existence of Allah the Creator; and the rules that govern the relationship between humans and God The Almighty, humans with fellow humans, and humans with nature. As a caliph on earth, humans have the task of prospering the earth through equitable economic activities that care for the environment. The implication is that structured adjustments are needed towards the realization of an Islamic economic system which regulates ownership rights in the use and distribution of assets. Utilization of assets in the form of development in agricultural, industrial, and commercial sectors is limited by Islamic values.

In practical level, efforts to integrate dimensions of SDGs within the "Umranic framework" will be reflected in market mechanism instruments by the choice of utilizing assets in certain economic sectors that are allowed by Islamic rules with clarity of ownership and management patterns of business cooperation (Syirkah) based on profit sharing. The economic activity in question is very concerned about environmental quality. Meanwhile, non-market mechanism activities are carried out through optimization of charity funds, zakat, infaq, sadaqah and waqf for economic empowerment that prioritizes the principles of sustainable development. A concrete example is creating economic activities that care about environmental sustainability by involving community participation, which is strengthened by the management under economic institutions that practise profit sharing.

\section{Acknowledgments}

We wish to thank the Directorate of Higher Education Ministry of Research and Technology Indonesia for financially supporting this study through the International Research Collaboration and Scientific Publication Grant, 2019.

\section{References}

Abdulrachman, S. M. (2011). Integrating Spiritual Dimension in Sustainable Development Strategy an Islamic Perspective. OIDA International Journal Sustain Development, 2(11), 51-64. Retrieved from http://www.ssrn.com/link/OIDA-Intl-Journal-Sustainable-Dev.html

Abdurrahman. (2012). Memelihara Lingkungan Dalam Ajaran Islam. Bandung: Penerbit Rosda Karya.

Al-Jayyousi, O. R. (2012). Islam and Sustainable Development. Surrey: Gower Publishing, Ltd; 20AD.

Al-Maliki, A. (2009). Politik Ekonomi Islam. Al-Azhar Press.

Al-Nabhani, T. (2010). Sistem Ekonomi dalam Isam (Terj). Jakarta: HTI Press.

Aziz, A., \& Ulfah, M. (2010). Kapita Selekta Ekonomi Islam Kontemporer. Bandung: Penerbit Alfabeta Bandung.

Babbie, E. R. (1980). The Practice of Social Research. Wardworst Publishing.

Blanc D, Le. (2015). The sustainable development goals as a network of targets. Monitoring and Evaluation NEWS. Dep Econ Soc Aff., 1(141), 1-17. https://doi.og/10.1002/sd.1582

Briassoulis, H. (2001). Sustainable development and its indicators: Through a (Planner's) glass darkly. Journal Environ Plan Manag., 44(3), 409-27. https://doi.org/10.1080/09640560120046142

Chalil, Z. F. (2009). Pemerataan Distribusi Kekayaan Dalam Ekonomi Islam. Jakarta: Penerbit Erlangga.

Counsell, D. (1999). Attitudes to sustainable development in planning: Policy integration, participation and Local Agenda 21, a case-study of the Hertfordshire Structure Plan. Local Environ., 4(1), 21-32. https://doi.org/10.1080/13549839908725578

Dariah, A. R., Sundaya, Y., Malik, Z. A. (2014). Enriching the Theory of Factor Pricing and Income Distribution in Islamic Perspective. Journal Of Social Sciences Research, 5(3), 872-881.

Hafsa, Z., \& Aström, O. (2011). Paradigm Shift for Sustainable Development: The Contribution of Islamic 
Economics. Journal Econ Soc Stud., 1(1), 73-82. Retrieved from http://eprints.ibu.edu.ba/1059/1/vol1-no1-p73-82.pdf

Holden, M. (2008). The tough minded and the tender minded: A pragmatic turn for sustainable development planning and policy. Plan Theory Pract., 9(4), 475-96. https://doi.org/10.1080/14649350802481371

LSIPK (Lembaga Studi Islam dan Pengembangan Kepribadian) Unisba. (2017). Tafsir Juz XIV Universitas Islam Bandung. Bandung: Penerbit Lembaga Studi Islam dan Pengembangan Kepribadian (LSIPK) Unisba.

Muștafā, I. (1972). Al-Mu’jam al-Wasịṭ. Cet. 2 Al-Qāhiraț: Mujamma’ al-Lughat al-‘Arabiyyat. Matba’at Misr.

Nasim, A., \& Politik Ekonomi Islam. (2012). Politik Ekonomi Islam. Paper presented at Workshop of Ekonomi Islam Hizbut Tahrir Indonesia.

Nilsson, M., Griggs, D., Visbeck, M., Ringler, C., \& McCollum. (2017). A Framework for Understanding Sustainable Development Goal Interction. A Guide to SDG Interctions: From Science to Implementation : International Council for Science (ICSU). https://doi.org/10.24948/2017.01

Roberts, P., \& Chan, R. C. K. (1997). A tale of two regions: Strategic planning for sustainable development in East and West. Int Plan Stud., 2(1), 45-62. https://doi.org/10.1080/13563479708721668

Salleh, M. S. (2009). Pembangunan Berteraskan Islam. Kuala Lumpur: Publications \& Distributors SDN BHD.

Shari'ati. (2005). Menginsankan Diri. Buletin al-Huda Edisi, 172.

Triono, D. C. (2012). Ekonomi Islam Madzhab Hamfara. Jilid 1. Penerbit Irtikaz.

United Nation. (2015). Integrating the three dimensions of Sustainable Development: A Framework and Tools. Greening of Economic Growth Series. Economic and Social Commission for Asia Pacifik (ESCAP).

United Nation. (2018). The Sustainable Development Goals Report Vol. 19, United Nation. 2018. 77-82 p. Retrived from https://unstats.un.org/sdgs/files/report/2018/TheSustainableDevelopmentGoalsReport2018-EN.pdf\%0Ahttp ://ci.nii.ac.jp/naid/130003305678/

Weitz, N., HuberLee, A., Nilsson, M., Davis M., \& Hoff, H. (2015). Cross-sectoral integration in the Sustainable Development Goals : a nexus approach (Discussion Brief). Stockholm.

Yusnita, O. (2014). Sri Lovely: Pencetus Pertanian Organik, Lubuk Rezeki Koperasi Luar Bandar. Maktab Kop Malaysia., (43), 47-53.

\section{Copyrights}

Copyright for this article is retained by the author(s), with first publication rights granted to the journal.

This is an open-access article distributed under the terms and conditions of the Creative Commons Attribution license (http://creativecommons.org/licenses/by/4.0/). 